\title{
Entre versos e polêmicas: Jônatas Batista e a crítica literária em Teresina no início do século XX.
}

\author{
Between verses and controversies: Jônatas Batista and the literary \\ criticism in Teresina at the beginning of the 20 th century.
}

\section{Ronyere Ferreira da Silva ${ }^{1}$}

\section{RESUMO}

O presente artigo consiste na análise das polêmicas literárias ocorridas em Teresina, no início do século XX, privilegiando, sobretudo, a participação do escritor Jônatas Batista nesses eventos. Busca-se identificar os motivos geradores dessas polêmicas e os usos feitos delas no processo de autoafirmação dos jovens intelectuais. Tomam-se como fontes os jornais circulantes na cidade durante o período, especialmente críticas literárias, réplicas e tréplicas, assim como pequenas notas que informam sobre o movimento social. Entre os autores com os quais se dialogou, estão: Queiroz (1998), Magal hães (2016), Botelho (2011), De Luca (2011) e Ventura (1991).

Palavras-chave: Jônatas Batista. Teresina. Polêmicas literárias.

\section{ABSTRACT}

The present article consists of the analysis of the literary controversies that occurred in Teresina, at the beginning of the 20th century, privileging, above all, the participation of the writer Jônatas Batista in these events. It seeks to identify the causes of the se controversies and the uses made of them in the process of self-affirmation of young intellectuals. We used as sources the newspapers circulating in the city during the period, especially literary critiques, replicas and cheerleaders, as well as small no tes that inform about the social movement. Among the authors we dialogue with are Queiroz (1998), Magalhães (2016), Botelho (2011), De Luca (2011) and Ventura (1991).

Keyword: Jônatas Batista. Teresina. Literary controversies.

1 Mestre em História no Programa de Pós-Graduação em História do Brasil, da Universidade Federal do Piauí. Integrante do grupo de pesquisa "História, teatro, música e estética", cadastrado no CNPq.. 


\section{Introdução}

A produção literária no início do século XX em Teresina, capital do Piauí, era veiculada sobretudo por meio da imprensa periódica. Poesias, contos, crônicas, peças teatrais, entre outros gêneros, eram publicados, resenhados e debatidos insistentemente por meio de jornais e revistas que possuíam tamanho e periodicidade variados. $O$ presente artigo analisa as polêmicas literárias do período, perscrutando especialmente as que envolveram a trajetória de Jônatas Batista, ${ }^{2}$ escritor frequentemente envolvido nessas contendas, sobretudo na primeira década do século, quando ainda buscava se constituir como intelectual.

Compreende-se que, embora cada escritor possuísse suas especificidades de literato e polemista, a trajetória de Jônatas Batista permite o desvelamento dos usos e abusos das polêmicas literárias, consideradas momentos preciosos para a conquista de público, para a formação de uma consistente literatura local e para a exibição de qualidades/conhecimentos individuais.

Nesse estudo, analisamos periódicos circulantes em Teresina, entre eles $O$ Operário, Diário do Piauí, O Monitor, $O$ Apóstolo e $O$ comércio. No contato com essas fontes, amparamonos em estudos que compreendem essas publicações como projetos sociais coletivos, alertando-nos ainda para sua diagramação e hierarquia interna, pois esses elementos informam sobre a importância dada aos textos e a seus autores (BOTELHO, 2011; LUCA, 2011).

Busca-se compreender esses periódicos como integrantes do movimento social. Os textos literários e as críticas veiculados, assim como as crônicas, possuíam íntima ligação com seu tempo e espaço de produção, comportando em si forte desejo de intervenção no social (CHALHOUB; NEVES; PEREIRA, 2005).

\section{Compor, publicar, polemizar}

Compor e publicar poemas nas primeiras décadas do século XX eram práticas valorizadas em meio aos homens letrados em Teresina, ser hábil ou assíduo na produção de

${ }^{2}$ Jônatas Batista nasceu em 1885 no povoado Natal, faleceu em1935, em São Paulo. Ainda criança mudou-se para Teresina, onde estudou até o secundário. Foi escrivão da antiga Mesa de Rendas, subdelegado de polícia, jornalista, dramaturgo, cronista e poeta, foi um dos fundadores da Academia Piauiense de Letras e destacou-se por sua militância cultural. Publicou dois livros de poemas, Sincelos (1906)e Alma sem rumo (1934). Redigiu e colaborou com vários jornais no Piauí e em outros estados. Conferir: (FERREIRA, 2015, p. 143-151). 
rimas eram qualidades necessárias para alcançar o reconhecimento social como intelectuais. Conforme destacou Teresinha Queiroz, "um bacharel em direito que não escrevesse em jornal, fizesse conferências públicas ou compusesse poesias era considerado burro" (QUEIROZ, 1998, p. 108).

Nesse período, a maioria dos periódicos possuíam produções literárias em seu conteúdo, sobretudo poesias, ocupando quase sempre locais de destaque na primeira página. Essa valorização hierárquica conferida à literatura nos jornais, deve-se tanto ao perfil de seus redatores, que produziam e buscavam a valorização da literatura, quanto ao objetivo de alcançar o maior e mais diversificado público possível, alcance que poderia se converter em renda e possibilitar a manutenção das publicações.

Essas poesias possuíam diversas finalidades, serviam como flertes amorosos ou políticos mais ou menos velados, como mecanismos de construção de laços sociais e culturais, e até mesmo como pilhérias políticas mais agressivas. Considerada uma manifestação cultural apurada, não se fazia um sarau, uma festividade religiosa ou uma solenidade oficial sem que nela estivesse um poeta com seus versos, esperando a devida hora de declamá-los e ouvir soberbos aplausos. Segundo Teresinha (QUEIROZ, 1998, p. 169), a poesia era revestida da mesma finalidade das demais produções escritas da época, servindo "como instrumento privilegiado e eficaz de ação e interferência no âmbito social" em que os autores estão inseridos.

Em meio a essa manifestação elegante, Jônatas Batista era presença constante em diversas festividades na cidade, ocasiões em que declamava poemas de sua autoria. Em um festejo organizado pela associação Tiro de Guerra n. 79, pelo "sr. Jônatas Batista foi recitado o belo soneto 'Saudação à Bandeira', de sua lavra" (TIRO..., 1910, p. 2); em abril de 1916, divulgava-se o baile que ocorreu em homenagem ao então Senador Abdias Neves, dentre a descrição do ocorrido, frisa-se que, de forma rápida e vibrante, Jônatas Batista teria oferecido a festa ao Senador e sua família (SENADOR..., 1916, p. 2).

Entretanto, além de afáveis notas na imprensa, as produções literárias no período renderam diversas farpas. Com frequência circulavam, por meio dos periódicos da cidade, polêmicas literárias que representavam um dos principais divertimentos dos leitores. Nesses embates os intelectuais faziam amplo uso de conhecimentos variados, discorrendo sobre as normas gramaticais, as tendências literárias, os conteúdos das produções e muitas vezes recorriam às ofensas pessoais como forma de desqualificar os adversários.

Essas características das polêmicas no início do século $\mathrm{XX}$, cuja frequência caiu progressivamente nas décadas seguintes, foram herdadas dos clássicos embates oitocentistas. Durante a segunda metade do século XIX foram inúmeras as polêmicas que envolveram literatos renomados, a exemplo de Sílvio Romero, José de Alencar, Joaquim 
Nabuco, José Veríssimo e Araripe Júnior, no Rio de Janeiro, e Júlio Ribeiro em São Paulo. ${ }^{3}$ Essas controvérsias explicitavam as diferenças entre as gerações de escritores, seus vínculos pessoais e as concepções literárias e filosóficas que nutriam, seja no tocante a questões estéticas e temáticas ou à função da literatura.

Sobre a variedade de assuntos tratados durante as polêmicas e a tentativa de se sobrepor ao oponente, Eduardo Vieira Martins ao analisar o embate entre José de Alencar e Joaquim Nabuco, ${ }^{4}$ destacou:

\begin{abstract}
Além de questões concernentes ao teatro e ao romance, outros temas foram debatidos pelos dois polemistas, desde problemas literários relevantes até a miuçalha sem qualquer importância que sempre se levantava nesse tipo de debate, apenas com o intuito de 'dar quinau' no oponente e afirmar a própria superioridade. No século XIX, a polêmica era um gênero prestigioso e uma forma socialmente reconhecida de um escritor projetar-se na arena pública, angariando o reconhecimento dos leitores. (MARTINS, 2010, p. 29)
\end{abstract}

As polêmicas literárias, ainda frequentes em Teresina na primeira década do século $\mathrm{XX}$, dividiam opiniões, proporcionavam a formação de partidos e eram dos assuntos mais comentados em meio a uma elite cultural mais próxima dos ambientes letrados, interesse que muitas vezes se mantinha durante semanas ou meses. Segundo Teresinha Queiroz, as polêmicas em Teresina, nas primeiras décadas do século $\mathrm{XX}$, não se restringiam às questões literárias, eram práticas assíduas e diversificadas:

"O polemismo é uma característica chave do período e relaciona-se não só à literatura e as questões gramaticais, mas igualmente com a política, a religião, os costumes. São notáveis as polêmicas anticlericais e as de natureza política, que marcam também a produção literária". (QUEIROZ, 1998, p. 109).

Dentre as polêmicas ocorridas em Teresina, uma das mais ruidosas e tensas foi a que envolveu a obra Ode a Satã, de Adalberto Peregrino, então delegado fiscal do Ministério da Fazenda no Piauí. Nesse embate, depois de semanas de polêmicas, ambos os lados deixaram

\footnotetext{
${ }^{3}$ Sobre as polêmicas nas últimas décadas do século XIX e primeiras décadas do século XX, especialmente as inúmeras envolvendo Sílvio Romero, consultar Roberto Ventura (1991, p. 71-161). Sobreas polêmicas de Júlio Ribeiro, consultar Célia Regina da Silveira (2008).

${ }^{4}$ Uma das polêmicas literárias da segunda metade do século XIX mais comentadas, travada nas páginas do jornal fluminense $O$ Globo, em 1875. Joaquim Nabuco, recém-chegado da Europa, empreendeu um esforço crítico de minimização da obra de José de Alencar, que rebatia semanalmente as colocações do jovem aspirante às letras. Entre seus analistas estão Eduardo Vieira Martins (2010), Roberto Ventura (1991, p. 44-47) e Roberto Schwarz (2012).
} 
o campo da erudição literária para se desenvolverem sobre outros assuntos e trocarem acusações e ameaças. A questão movimentou a imprensa e o meio intelectual, vári os jornais publicaram os diversos artigos e contra artigos da polêmica, entre eles $O$ Apóstolo, ${ }^{5} \mathrm{O}$ Monitor $^{6}$ e O Comércio. ${ }^{7}$

Em defesa de Adalberto Peregrino, publicaram-se artigos nos jornais $O$ Monitor e $O$ Comércio, enquanto seus oponentes faziam uso das páginas do periódico O Apóstolo, com ferrenhas críticas à Ode a Satã. Segundo os redatores do jornal católico, eles só teriam se envolvido na polêmica porque, tendo Adalberto Peregrino acreditado que seus censores seriam padres, deixou a defesa de sua obra para dedicar-se a críticas à Igreja e ao clero da cidade:

Baldado esse passo do Sr. Peregrino, julgou ele que o velho Fagundes fosse um padre; foi às colunas dos jornais desfechar um artiguete contra o clero, errado até no título, e descompôs os mais altos representantes da Igreja, de um modo brutal, e assim achou que tinha respondido ao seu crítico. (COMO..., 1907, p. 2).

O redator questionou o procedimento de Adalberto Peregrino e destacou que as acusações teriam o mesmo valor de "acusações erguidas pelos despeitados inimigos de Deus". Denunciou ainda que o autor de Ode a Satã teria feito de uma questão literária outra de cunho religioso, e que teria ele feito uso de pseudônimos para professar mentiras e prometer divulgar uma novela contendo diversas denúncias morais ao clero teresinense.

No mesmo artigo, o redator convocava Adalberto Peregrino a divulgar a novela citada, assim como as provas de tais acusações. Como retaliação, prometia levar ao conhecimento do Ministro da Fazenda o comportamento de seu representante no Piauí, que além de exercer o cargo de delegado fiscal, seria "um polemista que insulta e fere a honra do clero piauiense, da Igreja Católica e dos seus mais altos representantes" (COMO..., 1907, p. 2).

\footnotetext{
${ }^{5}$ Jornal semanal pertencente à Diocese de Teresina que iniciou sua circulação em1908. Teve como principal redator Elias Martins, combatendo em especial a Maçonaria e os jornais críticos à Igreja Católica e seu clero, entre eles $O$ Comércio e $O$ Monitor. Trazia crônicas sobre o cotidiano com fortes críticas às sociabilidades tidas como modernas e ao gove rno de Miguel Rosa, funcionava como mecanismo de intervenção, à luz do catolicismo, nos diversos aspectos da vida social do Piauí.

${ }^{6}$ Jornal anticlerical surgido em 1905, sua redação ficou a cargo de diversos intelectuais em diferentes fases. Entre seus colaboradores encontram-se Abdias Neves, Jônatas Batista, Zito Batista e Antônio Chaves.

${ }^{7}$ Jornal noticioso dirigido por Totó Rodrigues. Circulou de 1906 a 1912, contendo quatro páginas. Possuía pouca colaboração dos intelectuais locais, mas sempre veiculava textos de literatos conhecidos nacionalmente - Coelho Neto, Machado de Assis - e muitas notícias de outros Estados.
} 
Ainda sobre o livro de Peregrino, alguns artigos com pareceres foram publicados, em um deles, Jônatas Batista elogiou o talento do poeta e analisou Ode a Satã de forma favorável, apontou defeitos somente no que considerou excesso de dedicatórias e na parte formal, que, segundo o literato, deveria variar o uso da métrica, pois fazia uso durante toda a obra de versos alexandrinos (MAGALHÃES, 2016, p. 187-191).

A polêmica envolvendo Ode a Satã extrapolou o espaço das páginas dos periódicos. Adalberto Peregrino, alegando ter sido insultado com as críticas contidas nos textos veiculados em $O$ Apóstolo, acionou a justiça para que os originais fossem apresentados, exibindo-se assim os responsáveis por trás dos pseudônimos. Em resistência, o diretor do $O$ Apóstolo, Elias Martins, ${ }^{8}$ negou-se prontamente a comparecer à audiência, alegando ser uma tentativa se censura, que feria assim os princípios constitucionais de liberdade de pensamento da imprensa e da tribuna, segundo preconizava o $§ 12$ do art. 72 da Constituição de 1891 (BRASIL, 1891; PELO..., 1907, p. 2).

Outra polêmica ocorrida no período envolveu os poetas Costa e Silva ${ }^{9}$ e Benedito Pestana, ${ }^{10}$ motivada por críticas do segundo aos poemas produzidos pelo outro, contenda que perdurou por meses. Nessa polêmica, o tema central debatido foi o uso correto do português, referente à sintaxe, ortografia e semântica. Como de costume, acabou em ofensas pessoais proferidas de ambos os lados. Em alguns momentos esse debate teve intermédio de Jônatas Batista, por meio da coluna "Sessão particular", que mantinha no jornal Gazeta (MAGALHÃES, 2016, p. 110-111).

Contudo, Jônatas Batista não se restringiu à mediação de polêmicas, envolveu-se diretamente em pelo menos duas na primeira década do século XX. Primeiramente com Benedito Pestana, devido aos usos da temática do "amor" na produção poética local, e posteriormente com Esmaragdo de Freitas, em meio aos diversos pareceres literários sobre seu primeiro livro de poemas, Sincelos, publicado em 1907.

As controvérsias com Benedito Pestana ocorreram em 1906 por meio das páginas dos jornais $O$ Operário ${ }^{11}$ e Andorinha, ${ }^{12}$ contudo, somente foi possível a recuperação do último

\footnotetext{
${ }^{8}$ Elias Firmino de Sousa Martins nasceu em 1869 em Picos e faleceu em 1936 em Teresina. Bacharel, político, jornalista, foi o principal redator do jornal católico $O$ Apóstolo, onde criticava ferrenhamente as diversões modernas, as mudanças nos costumes tradicionais e os governantes maçons do Piauí entre os anos de1910 a 1916. Entre seus livros encontram-se O Poder das Trevas (1913), Frei Serafim de Catânia (1917), Guerra Sectária e Fitas (1920).

${ }^{9}$ Antônio Francisco da Costa e Silva Júnior, mais conhecido como "Da Costa e Silva", nasceu no ano de 1885 na cidade de Amarantes(PI), e faleceu em 1950 no Rio de Janeiro. Poeta, crítico literário e jo rnalista. Saiu do Piauí em 1906 para cursar Direito em Recife, residiu posteriormente em Porto Alegre, São Paulo e Rio de Janeiro. Na época em que residia em Teresina, assinava somente "Costa e Silva”. (MAGALHÃES, 2016, p. 110; GONÇALVES, 2000, p. 66-71).

${ }^{10}$ Benedito Pestana nasceu em Altos (PI) no ano 1884, faleceu na cidade Teresina em 1965. Foi farmacêutico, poeta e jornalista, colaborou em jornais no início do século XX, entre eles O Norte e Andorinha. (ADRIÃO NETO, 1995, p. 202).

${ }^{11}$ Publicação semanal de quatro páginas iniciada em 1906. Tinha como redatores Jônatas Batista e M. Saraiva de Lemos, era o principal jornal voltado para trabalhadores em Teresina, com notícias frequentes sobre sindicatos de outras cidades e estados. Foi o principal órgão de apoio às comemorações do Dia do Trabalho de 1906, contando com a colaboração de alguns intelectuais do período, entre eles Higino Cunha, Totó Rodrigues, Zito Batista e Nei da Silva.
} 
artigo de cada poeta. $O$ escrito de Benedito Pestana inicia-se com a declaração do enterro de Jônatas Batista, por este ter direcionado o debate à enfermidade da "poetalogia". Segundo o literato destaca, é possível inferir que Jônatas Batista tenha recorrido a escritores consagrados da literatura mundial, nacional e local com o intuito de legitimar o sentimento que defendia, dentre eles Guerra Junqueira, Casimiro de Abreu, Victor Hugo e Higino Cunha. ${ }^{13}$

Jônatas Batista defendeu o amor como um sentimento benéfico ao homem, opondo-se assim a Benedito Pestana, que fez uso dos comentários de vários autores clássicos e do convívio social de ambos, todos contendo conceituações em detrimento ao sentimento:

'Jonas da Silva' - Amor, termo banal, vocábulo caduco...

'Hamilton' - O amor é um mal contagioso que torna frenéticos os que ele domina.

Padre 'Du Bosc' - O amor é um cego malicioso que não quer senão furar os olhos do guia, a fim de se perderem juntos.

‘Bacon' - O amor é perturbador do mundo. (PESTANA..., 1906, p. 3)

Por fim, declarou que os autores não teriam escrito sob a influência do despeito ou de sentimentos similares, e despede-se dizendo “Adeus, Jônatas. A terra te seja leve!...". Em ambos os artigos se observa o uso retórico do que Roberto Ventura (1991, p. 85) chamou de "fontes de autoridade", artifício usual no qual os polemistas buscavam demolir as ideias dos oponentes pela referência a autores reconhecidos e valorizados, tanto pelos pares, quanto pelo público leitor.

Em resposta à provocação e igualmente em tom de troça, Jônatas Batista declara que mesmo se estivesse morto, ainda assim seria capaz de fazer estremecer seu adversário:

Mesmo depois de meu enterro, isto é, mesmo depois de morto, eu ainda poderia fazer tremer o pensador se já não tivesse dito que não mais voltaria ao assunto de nossa polêmica, tão desastrada quão mal empreendida pelo vencedor vencido da 'Andorinha'. (BATISTA, 1906a, p. 3, grifo do autor).

\footnotetext{
${ }^{12}$ Periódico bissemanal, literário, crítico e noticioso. Era uma publicação do Grêmio Literário "12 de Outubro": Pedro Cunha, Aarão Parentes, Esmaragdo de Freitas, Celso Pinheiro, Da Costa e Silva, Benedito Pestana e Raimundo Cunha. (PINHEIRO FILHO, 1972, p. 90-91).

${ }^{13}$ Higino Cícero da Cunha nasceu em 11 de janeiro de 1858, em Timon. Morreu em 16 de novembro de 1943. Magistrado, professor, historiador, jornalista, poeta. Foi um dos fundadores da Academia Piauiense de Letras, entre suas obras encontra-se $O$ ideal filosófico e o ideal artístico; e História das religiões no Piauí. (ADRIÂO NETO, 1995, p. 97).
} 
Na continuação do artigo, o literato acusou Benedito Pestana de não responder às perguntas presentes em seu texto anterior e de ter se transformado em "coveiro do cemitério dos gaiatos". Para finalizar, declarou que, independentemente de seus sentimentos, fossem eles oriundos da felicidade ou da consternação, sempre defenderia o amor (BATISTA, 1906a, p. 3-4).

Esse desfecho da polêmica pouco passou da erudição, os últimos artigos, inclusive, não transpareceram sequer seriedade. Dito de outra maneira, parece-nos que essa polêmica se tratava de um recurso jornalístico com o intuito de angariar leitores. Reforça essa hipótese o fato de ambos os artigos estarem publicados pelo jornal $O$ Operário, redigido pelo próprio Jônatas Batista, um texto seguido do outro, sendo que o de Benedito Pestana encontra -se em local privilegiado na primeira página.

Possivelmente, Jônatas Batista reproduzia o escrito de seu adversário veiculado em outro periódico, o que garantia a visão contínua do embate por parte do público leitor. Desse modo, esta polêmica, assim como outras, pode ser lida como um intento de atrair a atenção social, com um desenrolar premeditado, buscando assim contribuir para a produção de um público leitor, ainda incipiente na cidade.

No entanto, se essa hipótese se confirma, certamente não predominava. Diversas outras polêmicas se originaram no campo dos interesses coletivos e individuais, assim como por contendas anteriores, internas ou externas ao campo literário. A controvérsia envolvendo Jônatas Batista e Esmaragdo de Freitas, ${ }^{14}$ ocorrida em 1907, é representativa nesse sentido. Apesar de ter como pano de fundo a publicação do livro Sincelos, pode ser lida como mais um capítulo das disputas entre os dois literatos, iniciadas no ano anterior, quando quase protagonizaram uma tragédia na cidade.

Sincelos, ao ser publicado em 1907, foi objeto de diversas análises veiculadas por meio dos periódicos de Teresina, com pareceres discordantes. Essas críticas literárias, quando favoráveis, por vezes possuíam o objetivo de legitimar os amigos e valorizar suas obras, seja em âmbito local ou nacional (QUEIROZ, 1998, p. 110), ou com intuito oposto, quando se tratasse de produções de desafetos. Em ambos os casos, busca-se utilizar o poder e a penetração social do conteúdo dos jornais para influenciar a recepção das obras perante o público, mesmo quando minúsculo, como era o caso de Teresina na primeira década do século $\mathrm{XX}$.

\footnotetext{
${ }^{14}$ Esmaragdo de Freitas e Sousa nasceu em 1887 na cidade de Floriano (PI) e faleceu em 1946 no Rio de Janeiro. Foi magistrado, sociólogo, professor, escritor, jornalista e político. Saiu em 1907 para cursar Direito em Recife, retornando ao Piauí somente no final da vida. Entre suas obras: O Visconde da Parnaíba; Justiça piauiense; e Episódios históricos. (GONÇALVES, 2000, p. 177-178).
} 
Essa crítica literária tendenciosa, frequentemente era denunciada na cidade. Lucídio Freitas ${ }^{15}$ em 1912, por meio da enquete Piauí Intelectual, ${ }^{16}$ mantida no Diário do Piauí, ${ }^{17}$ perguntava se a literatura piauiense se encontrava estagnada. Em resposta, Jônatas Batista negou veementemente, contudo, destaca que haveria uma desvalorização resultante de uma imprensa parcial, que vivia basicamente de "anúncios e descomposturas, longe de ser um amparo, um estímulo, é, antes, um empecilho, um entrave às letras e às artes” (BATISTA apud MAGALHÃES, 2016, p. 86-87).

Contra essas supostas descomposturas da imprensa local, o literato se defendeu antecipadamente em ocasião da publicação de Sincelos. Em nota preliminar, Jônatas Batista destacou que não teria procurado padrinhos para prefaciar sua obra, isso porque considerava a prática desonrosa, e por que os versos eram simples e espontâneos. ${ }^{18}$

Nei da Silva, ${ }^{19}$ em artigo publicado no jornal $O$ Monitor, manifestou seu parecer sobre Sincelos e criticou o descaso da sociedade para com obras poéticas, que, segundo ele, dificultava a aceitação da publicação. No mesmo texto, alertou Jônatas Batista para o possível surgimento de "crítica de esquina", censuras tendenciosas, sem fundamentos e isenção.

Segundo Nei da Silva, amigo próximo de Jônatas Batista, Sincelos seria uma obra literária com qualidade, seguidora do parnasianismo, movimento literário cujo maior representante era Olavo Bilac. Destacou ainda a forte presença do pessimismo e do sensualismo, além de elogiar o uso de sonetos e as descrições feitas por Jônatas (SILVA apud MAGALHÃES, 2016).

Seguindo o caminho diverso, Pedro Brito elogiou a simplicidade e a naturalidade presente nas poesias de Jônatas Batista, contudo, identificou em Sincelos uma insegurança

${ }^{15}$ Lucídio Freitas nasceu em Teresina no ano 1894 e faleceu na mesma cidade em 1921. Bacharel em Direito, poeta, jornalista, professor. Foi idealizador da Academia Piauiense de Letras, ocupando a cadeira de número nove. Entre suas obras estão Alexandrinos (1912), em parceria com o irmão Alcides Freitas; Vida obscura (1917); e Minha Terra (1921). (GONÇALVES, 2000, p. 351-354).

${ }_{16}$ Pesquisa idealizada por Lucídio Freitas na qual direcionava perguntas a intelectuais piauienses. Participaram da enquete Clodoaldo Freitas, Nilo Brito, Higino Cunha, Otávio Falcão, Luiz e Silva, Honório Parentes, Valdevino Tito, Abdias Neves, Jônatas Batista, Arimatéa Tito, Francisco Parentes, Zito Batista, Fenelon Castelo Branco e Silva Mendes. As perguntas variavam sobre questões diversas da literatura piauiense, entre elas: intelectualmente, qual o mais notável dos piauienses mortos? Que papel representa o Piauí no momento literário do país? Quais os tipos mais representativos do Piauí intelectual? É promissora a nova geração e qual seus principais representantes? Atravessamos uma época de estacionamento intelectual? (MAGALHÃES, 2016, p. 83-89).

${ }^{17}$ O Diário do Piauí era o jornal oficial do estado, circulou em Teresina de 1911 a 1914. Seu redator chefe era Simplício Mendes. Além do expediente oficial e dos atos do poder executivo, publicava poesias, crônicas e folhetins. Contava com a colaboração de diversos literatos piauienses, entre eles Clodoaldo Freitas, Higino Cunha, Lucídio Freitas, Jônatas Batista, Antônio Chaves, Zito Batista e Abdias Neves.

${ }^{18} \mathrm{O}$ autor deste livro, embora reconheça que os seus prelúdios se não recomendam muito pelo merecimento literário, é d'aqueles que entendem que o prefácio não é mais do que o elogio descarado e irrisório, ou a covardia dos principiantes. Resolveu, por isso, não procurar padrinho para seus versos, tendo, como alívio de consciência, uma certeza: - Se os seus rascunhos, os seus ensaios, não têm nenhum valor para os que sabem medir heroicos e alexandrinos, pelo menos lhe não deram muito trabalho; não foi preciso martelar o juízo para escrevê-los. Nasceram espontâneos, naturalmente espontâneos, para o amor e pelo amor. E agora, que julguem os competentes. (BATISTA, 1907b, p. 3).

${ }^{19}$ Nei da Silva foi jornalista e poeta, colaborador assíduo dos periódicos teresinenses nas primeiras décadas do século XX. 
que incapacitava seu autor de alcançar grandes louvores. Pedro Brito criticava o que considerava excesso de apego à temática do amor, apesar de reconhecer que o sentimento era o principal objeto dos poetas (BRITO apud MAGALHÃES, 2016).

Antônio Bona, ${ }^{20}$ por sua vez, apreciou Sincelos em seu artigo intitulado "Pela estética", publicado pelo jornal $O$ Comércio, no qual inicia discorrendo sobre as diferenças entre o poeta e o crítico literário. O segundo, conforme argumentou, "tem o sentimento poderoso da justiça". Ao frisar uma suposta imparcialidade, o crítico buscou legitimar sua função e convencer o leitor sobre sua sinceridade e neutralidade, influenciando assim na recepção da obra. Bona elogiou a coragem de Jônatas Batista ao publicar seu primeiro livro em meio a uma sociedade cada vez mais materialista e avessa à cultura, contudo, declarou ser o próprio Sincelos o ponto fraco do literato (BONA, 1907, p. 1).

Claramente desfavorável, Antônio Bona classificou a coragem de Jônatas Batista como prematura, não sendo a hora mais adequada de dar publicidade aos seus poemas em forma de livro. Por meio desse artigo, e dos publicados por Nei da Silva e Pedro Brito, explicitam-se duas características da crítica literária do período, a parcialidade e a pessoalidade. Antônio Bona, por trás de disfarce pouco convincente, desqualifica Sincelos e censura o suposto exibicionismo de Jônatas, declarando escaparem somente quatro ou cinco sonetos de seu livro.

\begin{abstract}
Mas o prurido da exibição não se coaduna com estes exemplos. E é este o maldito prurido que atacou o nosso Jônatas e eis porque a sua estreia em volume lhe não conquistou os loiros sonhados. Verdade é que os seus versos não são todos maus, medíocres, incolores; porém, com franqueza, não são bons. Uns quatro ou cinco sonetos e duas quadrinhas da poesia Delito salvam-no do naufrágio. [...] As suas queixas e seus lamentos são feitos em acentos ternos, delicados, falando ao coração, mas sem os surtos arrebatadores do moderno lirismo brasileiro, sem belezas de forma, sem originalidade, sem imaginação, enfim. Até o vocabulário é exíguo, como exíguas são as ideias repisadas. (BONA, 1907, p. 1)
\end{abstract}

Do trecho destacado ao fim do artigo, outras críticas são desfechadas ao livro e ao autor, que doravante debutava na literatura piauiense em forma de voluma. Para terminar as censuras a Sincelos, Antônio Bona critica a insistência em temas amorosos, ausência de questões filosóficas, temas novos ou mesmo de imaginação.

\footnotetext{
${ }^{20}$ Antônio Bona nasceu na cidade de Campo Maior em 1887, faleceu no Rio de Janeiro em 1965. Foi magistrado, jurista, professor e crítico literário. Sua vida prática foi desempenhada principalmente no Maranhão. Ocupou a cadeira trinta da Academia Piauiense de Letras. Publicou Razões de apelação (1931). (GONÇALVES, 2000, p. 52).
} 
O artigo de Antônio Bona novamente coloca o público leitor diante da parcialidade da crítica literária no início do século XX. Claramente, o intuito de seu artigo é minimizar ao máximo a publicação de Jônatas Batista e prejudicar sua recepção, já que não é impossível atribuir-se esse intento às contendas amorosas ocorridas em 1906 entre os dois, existentes e lembradas pelo próprio censor: "cremos que não se verão neste nosso juízo, tão francamente externado, intenções inconfessáveis, traços de vingança das nossas lutas de amor do ano passado".

Outro ponto importante no desenrolar das críticas que envolvem Sincelos é a participação do jornal $O$ Comércio, não sendo exagerado apontar uma conivência do redator do periódico com as apreciações feitas ao livro de Jônatas Batista, cabendo ainda inferir que tal procedimento pode ser atribuído à influência de Esmaragdo de Freitas, que mesmo cursando Direito em Recife, continuou colaborando ativamente com o periódico, como representante no estado em que residia.

Nos anos de 1906 e 1907 nota-se sempre a participação do jornal $O$ Comércio veiculando artigos em defesa de Esmaragdo de Freitas ou de sua autoria, quando atacado ou atacando Jônatas Batista, assim ocorreu pelo menos em três ocasiões. Outro aspecto que sugere essa tendência do jornal é a localização privilegiada que a crítica de Pedro Bona ocupa, na parte superior da primeira página.

Segundo informa Denílson Botelho, a diagramação de um jornal é regida por uma hierarquização interna para as matérias veiculadas, "pois sabe-se que uma matéria na parte superior da página tem mais chances de merecer a atenção do leitor" do que as que se encontram espremidas nas partes inferiores (BOTELHO, 2011, p. 23). Sobre essa divisão do que é publicado por jornais, Tania Regina de Luca destaca:

Entretanto, ter sido publicado implica atentar para o destaque conferido ao acontecimento, assim como para o local que se deu a publicação: é muito diverso o peso do que figura na capa de uma revista semanal ou na principal manchete de um grande matutino e o que fica relegado às páginas internas. (LUCA, 2011, p. 140).

Ao atentar para esse posicionamento, percebe-se a importância atribuída às críticas direcionadas ao livro de Jônatas Batista, pois, os artigos de Antônio Bona e Esmaragdo de Freitas encontram-se em destaque na parte superior da primeira página de $O$ Comércio. $\mathrm{O}$ parecer de Esmaragdo de Freitas sobre Sincelos foi a apreciação mais agressiva e jocosa sobre o livro, quebrando o silêncio do autor. 
Essa polêmica envolvendo Jônatas Batista e Esmaragdo de Freitas possivelmente não se originou em divergências estéticas ou literárias, mas em continuidade às hostilidades existentes entre os dois literatos. Em 2 dezembro de 1906, Jônatas publicou no jornal $O$ Comércio, por meio da coluna "Postais", críticas a algumas personalidades letradas de Teresina, entre elas Benedito Pestana e Esmaragdo de Freitas, o segundo foi acusado de ser afeminado, pretencioso e porta-voz do poeta Costa e Silva:

Ao 'formoso' e efeminado Esmaragdo de Freitas - o inconsciente portavoz do Costa e Silva e o fonógrafo aperfeiçoado do Dr. Ribeiro Gonçalves:

Seja menos pretensioso e ridículo. Quando tiver opinião própria, talvez lhe seja concedida a honra de uma polêmica. (BATISTA, 1906b, p. 3)

Destas acusações não se encontram respostas de Esmaragdo de Freitas. Em sua defesa, $O$ Comércio publicou em 16 de dezembro de 1906 um extenso artigo escrito por Costa e Silva. Por meio dessa resposta e do trecho destacado anteriormente, é possível inferir que as acusações de Jônatas Batista já seriam réplicas a censuras feitas anteriormente por Esmaragdo de Freitas sobre suas poesias, repreensões sobretudo à temática amorosa nutrida pelo poeta.

Na resposta de Costa e Silva, mesmo sem ser citado, Jônatas Batista foi descrito como um sujeito desequilibrado que se envaideceu com o surgimento dos primeiros elogios. Acusado de ser inventivo, de não ser poeta em uma terra sem literatura, onde qualquer esforço de crítica geraria inimizades e se transformaria em um crime contra o meio. Em oposição, busca valorizar a imagem de Esmaragdo de Freitas como um talentoso intelectual e homem respeitado na sociedade teresinense:

Criticar erros palpáveis deu motivo ao que, injustamente, se disse de meu talentoso amigo Esmaragdo de Freitas. Nunca pensei que o procedimento de meu digno colega produzisse tanta dinamite.

Não admito, porém, que se propale o que, sem provas, foi dito. Esmaragdo de Freitas é hábil, tem opinião própria e o estudo necessário para comprovar as suas ideias, aliando a todos estes predicados a nobreza de um caráter imáculo [...]. (SILVA JUNIOR, 1906, p. 2, grifo do autor). 
Ainda em dezembro de 1906, noticiou-se pela imprensa um evento no qual Esmaragdo de Freitas teria tentado assassinar Jônatas Batista com um tiro, após troca de agressões físicas em rua pública. Segundo Jônatas Batista, esse conflito teve início com a publicação de injúrias e insultos sobre sua vida particular em um jornal em 1906. Ao buscar satisfações, teria arremessado o jornal ao rosto do oponente, que em reação teria desfechado um tiro.

A sequência do desafeto seria a análise de Esmaragdo de Freitas ao livro de seu oponente, veiculada por meio do jornal o Comércio, após ser remetida do Recife, onde o literato cursava a Faculdade de Direito. Em seu diagnóstico, destacou que Sincelos não possuía nada de aproveitável, a não ser o título. Denunciou ainda a suposta existência de erros de sintaxe, concordância e vícios de linguagem:

Diante disso, onde apoiar a pretensão do meu coestadano, dando à luz um folheto em que deprime e fere os mais venerandos rudimentos da sintaxe? Vícios abomináveis de linguagem, erros rasteiros de concordância, estão aboletados ali muito descaradamente. Montado no pleonasmo, com o barbarismo à garupa. (FREITAS, 1907, p. 1).

Cada parágrafo da crítica é composto de zombarias acerca dos poemas e do poeta, abordando tanto as temáticas quanto o vocabulário presente em Sincelos que, segundo Esmaragdo de Freitas, seria "paupérrimo e viciado", com inúmeras repetições. Aponta erros diversos na métrica e ausência total de estética:

O meu patrício não tentou, ao menos, transpor as raias do vulgar e soltou um produto prosaico e chato [...] A sua poesia é péssima, cada frase é um disparate, cada verso uma ingenuidade. A estética nenhuma vantagem encontra nos Sincelos. A tendência natural para a perfeição, a irresistível preocupação do belo não lograram criar ânimo no espírito do piauiense, cujos versos, além de desenxabidos, caluniam, ferozmente, a arte. (FREITAS, 1907, p. 1).

Diante dos erros apontados, Esmaragdo de Freitas assinala que os poemas de Sincelos seriam "versos de pés quebrados", com monossílabos cuja única função seria "completar a 
medida, ou, em gíria popular, de encher a linguiça" (FREITAS, 1907, p. 2). Uma semana após a total desqualificação de seu livro, Jônatas Batista respondeu por meio do periódico $O$ Apóstolo, defendendo-se em longo artigo.

Jônatas Batista inicia seu texto destacando que não pretendia responder a nenhuma análise sobre seu livro, mas que Esmaragdo de Freitas teria lhe feito abandonar tal propósito, com o intuito de "provar até que ponto chegam a sua imbecilidade, o seu despeito e sua falta de escrúpulos assinando o que não escreve" (BATISTA, 1907a, p. 3). Para o literato, o verdadeiro autor da análise depreciativa teria sido o poeta Costa e Silva, amigo e defensor de seu oponente, colocando novamente sob dúvida sua capacida de de crítico. Jônatas Batista argumentou que seu desafeto teria recebido um exemplar de Sincelos seis meses antes da crítica ser publicada em Teresina, enquanto ainda estava na Bahia, contudo, teria esperado se encontrar com Costa e Silva, no Recife, que teria escrito o texto assinado por Esmaragdo de Freitas.

No decorrer do extenso artigo, que ocupa praticamente uma página inteira do jornal, Jônatas Batista refuta seu censor sobre os possíveis erros que teria cometido e cita diversos gramáticos e poetas renomados, entre eles Luís de Camões, Rui Barbosa e Guerra Junqueira, com o intuito de justificar que não havia empreendido nenhuma das falhas apontadas, seja na métrica ou na concordância de seus versos.

O artigo de Jônatas Batista segue basicamente as características das polêmicas literárias do período, discorrendo amplamente sobre questões de estética, normas gramaticais e destinando ofensas pessoais a seu adversário, seguidas de uma total desqualificação intelectual e moral de Esmaragdo de Freitas, que novamente é acusado de afeminado e tem suas relações com Costa e Silva colocadas sob suspeita:

Um tipo sem nome, um indivíduo sem recomendação, um desequilibrado cuja única propensão só o poeta do 'Sangue' poderá dizer. [...]

Eu poderia poupar-me a este trabalho [...] e qualquer pessoa por menos letrada que fosse, julgaria o grão de tuberculose da imbecilidade de que o Sr Esmaragdo está sendo vítima. [...]

Bufe, pois, grite, insulte, ladre, berre e assobie, com todos os seus iguais, formando uma orquestra acanalhada, eu me não incomodarei e nem lhe darei a honra de uma represália. (BATISTA, 1907a, p. 4)

Nessa polêmica, o poeta intercala indelicadezas e regras gramaticais em todo o texto, recorrendo a insultos sobre a vida privada de seus oponentes e agindo tipicamente como um 
polemista. Finaliza declarando que não mais responderia a seu adversário e deseja que Esmaragdo de Freitas "vá para o diabo que o carregue" (BATISTA, 1907a, p. 4).

Sem tréplicas de Esmaragdo de Freitas, surge então seu "muito distinto" amigo, Mário Abreu, tomando as dores por meio do artigo "Rebatendo", publicado no jornal o Comércio. Em seu texto, declarou a intenção de defender seus confrades, pois as afirmações de Jônatas Batista seriam "injuriosas, baixas e obscenas", pois Esmaragdo de Freitas teria tanto talento quanto Costa e Silva ao fazer críticas literárias. Ao passo que defendeu as qualidades imputadas ao amigo, Mario Abreu buscou desqualificar Jônatas Batista e seu livro, que na sua visão seria uma obra abaixo de qualquer crítica (ABREU, 1907, p. 3).

\section{Considerações finais}

Em 12 de março de 1912, o Diário do Piauí informava que em breve seria apresentado em Teresina o drama histórico Jovita ou a heroína de 1865, escrito por Jônatas Batista. Os frequentes lembretes exaltando a qualidade da obra e a expectativa do público deve-se, entre outros motivos, à forte estima que o literato dispunha na redação do periódico. Jônatas Batista era colaborador assíduo da folha, onde publicou poesias, crônicas e textos sobre teatro.

O literato ainda possuía íntimas relações com os redatores do periódico, a exemplo de Zito Batista, ${ }^{21}$ seu irmão, e Celso Pinheiro, ${ }^{22}$ amigo próximo, ambos revisores e colaboradores do jornal. Celso Pinheiro, ao assinar crônica com o pseudônimo "João Bizarro", assim descreveu o drama histórico de Jônatas Batista:

De certo, está um magnífico trabalho o drama histórico cuja leitura tivemos o prazer de ouvir naquela voluptuosa tarde de verão. É uma peça genuinamente piauiense [...] A facilidade espontânea das cenas, $o$ conjunto harmonioso dos períodos fazem-nos acreditar que por vezes a pena do jovem dramaturgo teve manejos inspirados de uma palheta

\footnotetext{
${ }^{21}$ Raimundo Zito Batista nasceu em 1887 e faleceu em 1926. Foi poeta, professor e jornalista, redigiu e colaborou em jornais no Piauí e outros estados. Entre suas obras estão: Almas Irmãs (1907), em parceria com Antônio Chaves e Celso Pinheiro; Chama Extinta (1918); Harmonia dolorosa (1924); e Poesias reunidas (1924). Cf.: GONÇALVES, 2000, p. 423-426; PINHEIRO, 2014, p. 184-185.

${ }^{22}$ Celso Pinheiro nasceu em 1887 e faleceu em 1950. Foi poeta, jornalista e cronista, com sua obra marcada pelo pessimismo. Ocupou a cadeira de número 10 da Academia Piauiense de Letras. Entre suas obras estão: Almas irmãs (1907), em parceria com Antônio Chaves e Zito Batista; Flor incógnita (1912); e Poesias (1939). (GONÇALVES, 2000, p. 121-123; MOURA, 2014, p. 10-12).
} 
maravilhosa. Em verdade, Jônatas Batista foi extraordinário na forma e na concepção dessa obra. (BIZARRO, 1913, p. 2)

A ocasião da leitura, citada por João Bizarro, teria ocorrido na casa de Jônatas Batista, em meio a uma das reuniões literárias que promovia. Suas considerações sobre a peça suscitam reflexões que podem ser expandidas à crítica literária do período. Uma delas, refere-se à proximidade que Jônatas Batista mantinha com o autor da análise e o periódico que a veiculou, sendo representativa de uma crítica literária formada por conhecidos, onde as relações sociais, simpatias e antipatias influenciavam tanto quanto os critérios analíticos.

Apesar dessas características da crítica teresinense, segundo se argumentou no decorrer desse artigo, os literatos ao atuarem como críticos, reivindicavam para si uma suposta isenção e impessoalidade, com o intuito de construir autorrepresentações favoráveis, capazes de legitimar uma eficaz intervenção na recepção das obras e nos interesses do incipiente público leitor de Teresina.

A crítica local, no início do século XX, seguindo tendências oriundas do século XIX, foi marcada por inúmeras polêmicas, muitas delas motivadas por questões pessoais. Essas controvérsias, eram arenas de disputas por poder na esfera intelectual e por reconhecimento social, vale ressaltar que Jônatas Batista, Esmaragdo de Freitas, Benedito Pestana e a maioria dos polemistas citados nesse artigo, integravam grupos de jovens literatos, que rivalizavam e buscavam se firmar no campo literário. Nesses acontecimentos, onde debatiam sobre temas variados, buscavam se sobreporem aos oponentes, seja por meio da demonstração de erudição e conhecimento, seja pela descompostura intelectual e moral dos adversários.

As polêmicas literárias tinham ainda a função de desenvolver a literatura local, por meio do embate entre os literatos e suas tendências, assim como ampliar o público leitor, atraído pelas controvérsias, forjadas ou desencadeadas, onde ambos os lados disputavam sua predileção. Por meio desses embates, os leitores eram convidados a tomar partido, a reconhecer vencedores, eram incentivados a consumir as produções literárias, os poucos livros publicados ou os diversos jornais circulantes.

\section{Referências}


ABREU, Mario. Rebatendo. O Comércio, Teresina, ano 2, n. 72, 3 nov. 1907. p. 3.

ADRIÃO NETO. Dicionário biográfico escritores piauienses de todos os tempos. Teresina: Halley, 1995.

BATISTA, Jônatas. Ainda o apalhaçado Esmaragdo de Freitas. O Apóstolo, Teresina, ano 1, n. 24. 27 out. 1907a. p. 3-4.

BATISTA, Jônatas. Mesmo depois de meu enterro [...]. O Operário, Teresina, ano 1, n. 3, 18 mar. 1906a. p. 3-4.

BATISTA, Jônatas. Postais. O Comércio. Teresina, ano 1, n. 23, 2 dez. 1906b. p. 3.

BATISTA, Jônatas. Sincelos. Teresina: Livro-Papelaria Veras, 1907b. p. 3.

BIZARRO, João. Um drama piauiense. Diário do Piauí, ano 3, n. 46, 21 fev. 1913. p. 2.

BONA, Antônio. Pela estética. O Comércio, Teresina, ano 2, n. 46, 12 maio 1907. p. 1.

BOTELHO, Denílson. Por uma história social da imprensa. In: NASCIMENTO, Francisco Alcides do; SANTOS, Maria L.; MONTE, Regianny L. (Org). Diluir fronteiras: interfaces entre História e Imprensa. Teresina: EDUFPI, 2011. p. 13-33.

BRASIL. Constituição da República dos Estados Unidos do Brasil. Índice dos atos do poder legislativo de 1891. Rio de Janeiro: Imprensa Nacional, [1892?]. p. 1-28. Disponível em <www2.camara.leg.br>. Acesso em: 7 jun. 2016.

CHALHOUB, Sidney; NEVES, Margarida de Souza; PEREIRA, Leonardo Affonso de Miranda. Apresentação. In: CHALHOUB, Sidney; NEVES, Margarida de Souza; PEREIRA, Leonardo Affonso de Miranda (Org.). História em cousas miúdas: capítulos de História Social da crônica no Brasil. São Paulo: Ed. da UNICAMP, 2005. p. 11-22.

COMO discute o Peregrino. O Apóstolo, Teresina, ano 1, n. 28, 24 nov. 1907. p. 2.

FERREIRA, Ronyere. Jônatas Batista: 'a volubilidade e a inquietude'. Revista da Academia Piauiense de Letras, Teresina, ano 97, n. 72, p. 143-151, 2015.

FREITAS, Esmaragdo. Correspondência. O Comércio, Teresina, ano 2, n. 70, 20 out. 1907. p. 1-2.

GONÇALVES, Wilson Carvalho. Antologia da Academia Piauiense de Letras. Teresina: [s. d.], 2000.

LUCA, Tania Regina de. História dos, nos e por meio dos periódicos. In: PINSKY, Carla Bassanezi (Org.). Fontes históricas. 3. ed. São Paulo: Contexto, 2011. p. 111-153. 
MAGALHÃES, Maria do Socorro Rios. Literatura piauiense: horizontes de leitura e crítica literária. 2. ed. Teresina: Academia Piauiense de Letras, 2016.

MARTINS, Eduardo Vieira. Nabuco e Alencar. O Eixo e a Roda, São Paulo, v. 19, n. 2, p. 15-32, 2010.

MOURA, Francisco Miguel de. Posfácio a literatura piauiense de João Pinheiro. Teresina: Academia Piauiense de Letras, 2014.

PELO fórum. O Apóstolo. Teresina, ano 1, n. 24, 27 out. 1907. p. 2.

PESTANA, Benedito. O enterro do polemista. O Operário, Teresina, ano 1,n. 3, 18 mar. 1906. p. 3.

PINHEIRO FILHO, Celso. História da imprensa no Piauí. Teresina: COMEPI, 1972.

PINHEIRO, João. Literatura piauiense: escorço histórico. 3. ed. Teresina: Academia Piauiense de Letras, 2014.

QUEIROZ, Teresinha. História, literatura, sociabilidades. Teresina: Fundação Cultural Monsenhor Chaves, 1998.

SCHWARZ, Roberto. Ao vencedor as batatas: forma literária e processo social nos inícios do romance brasileiro. 6. ed. São Paulo: Ed. 34, 2012.

SENADOR Abdias Neves. Correio de Teresina, Teresina, ano 4, n. 164, 4 abr. 1916. p. 2.

SILVA JUNIOR, Antônio da Costa e. Esmaragdo de Freitas. O Comércio, Teresina, ano 1, n. 25, 16 dez. 1906. p. 2.

SILVEIRA, Célia Regina da. Intervenções e polêmicas: Júlio Ribeiro no universo letrado paulista. ENCONTRO REGIONAL DE HISTÓRIA: Poder, Violência e Exclusão, 19., 2008, São Paulo. Anais... São Paulo: ANPUH/USP, 2008. p.1-9.

TIRO Piauiense. O Apóstolo, Teresina, ano 4, n. 172, 2 out. 1910. p. 2.

VENTURA, Roberto. Estilo tropical: história cultura e polêmicas literárias no Brasil. São Paulo: Companhia das Letras, 1991.

Recebido em 08/12/2016

Aprovado em 17/02/17 